\title{
Visual Inspection of Historical Buildings Using Micro UAV
}

\author{
Masiri Kaamin ${ }^{1, *}$, Noor Azyyati Idris $^{2}$, Saifullizan Mohd Bukari ${ }^{2}$, Zaurin Ali $^{2}$, Norhafiza \\ Samion ${ }^{1}$, and Mustaffa Anjang Ahmad ${ }^{2}$ \\ ${ }^{1}$ Pusat Pengajian Diploma, Universiti Tun Hussien Onn Malaysia, 86400 Batu Pahat, Johor \\ ${ }^{2}$ Smart Driving Research Center (SDRC), Fakulti Kejuruteraan Awam dan Alam Sekitar, \\ Universiti Tun Hussien Onn Malaysia,86400 Batu Pahat, Johor
}

\begin{abstract}
The historical building is one of the country's heritage that needs to be taken care of failures in design and structure. Damage or dilapidation study that conducted by Conservation of Historical Building Guide Lines that practices for documentation any problems and defects in buildings. The stages to be followed to determine the damage was shooting photos for every element studied. Photo has been taken directly or by using stair for higher parts of structures. Inspection of the historical building should be emphasized to ensure that the building is in a safe condition for long periods. This research aims is to investigate the historical building defects by using Unmanned Aerial Vehicle (UAV) to identify the type of defects occur at the exterior structure of museum. The case study is building of Perak Museum that located at Taiping, Perak. The process involved in this study are planning and preparation before the flight, data acquisition using UAV, image processing and analyzing data from video to image. The result of analysis, a total numbers of 91 locations have been identified and documented suffer from defects or faults such as frame decayed, vegetation, perforated pipe and crack. All defects information obtained suing UAV visual inspection can help the museum maintainance team for conservation and maintainace work.
\end{abstract}

\section{Introduction}

The historical building is an old structure and has its own unique aesthetics value in addition to the specific functions which caused the building ware gazette as historical buildings. Important historical research carried out for the scan and get a true picture of the historical appearance of the building and the environmental conditions during the era of the building was built [1]. In Malaysia, historical buildings are different form one another in terms of architectural style, function, structure and building defects which require a comprehensive approach to building conservation and systematic [2]. The inspection conducted at Perak Museum as case study for this research. There was several type of defect to the structure of the museum such as frame decayed, vegetation, perforated pipe

\footnotetext{
*Corresponding author: masiri@uthm.edu.my
} 
and crack. Previously, the inspection is usually done from very limited naked eye observation. UAV has being used as alternative way for collecting data visually for the exterior structure.

\section{Research background}

Survey the state of the building and damage known as dilapidation study. It is a process to identify and record the condition or degree of disability of the building. This study is a practice of documenting the problems and defects of the building is run [3]. The study is used to record and document, a thorough investigation is necessary to determine the condition of the building, the defect and the cause. Documentation in the form of digital and photography need to detect the circumstances and the nature of the materials of the existing building. Perak Museum was selected as study area because the history value and the first building undergoing conservation work.

According to J. Unger et.al, the high resolution camera attached to the UAV showed good results even under non-optimal flight conditions and confirmed that already visual recording methods provide valuable information for infrastructural inspection purposes [4]. Also the image post-processing has to be improved by reducing manual workflow by appropriate image stitching and mosaicking software, ideally with an integrated crack detection feature based on the results shown which still requires to be developed.

Due to management requirements in buildings, the risk of personal injury and damage to the infrastructure needs to be carried out as low as that may be. Redundancy factor therefore to position structures and parts of the complete system, then the reliability of flight important function, is a matter of paramount importance. Other major aspect was upon request to the characteristics of stable hovering to ensure planned and detailed examination of the damage

\subsection{Unmanned aerial vehicle}

Micro Unmanned Aerial Vehicle (UAV) equipped with a camera that offers the possibility to map the different areas quickly and with high flexibility compares to classic aerial photography. UAV also known as the Autonomous Navigation system because it is fly by using Global Positioning System (GPS) and support by the telemetry systems at the Ground Control Station (GCS) to monitor and navigate the UAV when capturing the data [5]. UAVs are becoming popular for use low budget and use in large scale mapping [6]. DJI Phantom FC40 used for this research as alternative ways for collecting data visually. Micro UAV able to fly less than 1 hour, limited load factor and optimum level of image quality that is useful between 800 feet to 1200 feet and an image resolution of $6 \mathrm{~cm}$ to $15 \mathrm{~cm}$ per pixel [7].

\section{Building inspection}

For building inspection of Perak Museum, UAV flight has been used for collecting data. This study followed several steps as the methodology. There are planning and preparation before fly, data collection using UAV, image processing from video to image and analysis of study.

Fig. 1 shows the UAV that has been used in this research. DJI Phantom FC40 is equipped with camera for recording image or videos. The recording will display through the smart phone that have install FC40 software. It comes with its own built in DJI 
designed smart camera with 720p/30fps HD video support, and iOS or Android app control. Using a $2.4 \mathrm{G}$ Wi-Fi connection, it provides a full FPV experience at up to $100 \mathrm{~m}$. [8] It's the ideal choice for those getting started with aerial cinematography. The software will be downloaded at Google Play to connect with the camera. The software will function when the smart phone and the camera were connected through the Wi-Fi application.

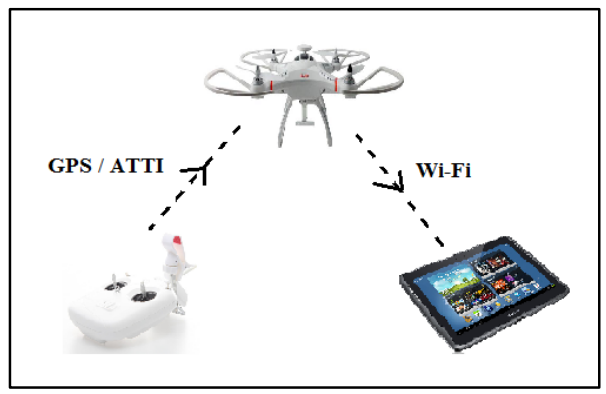

Fig. 1. Connection between remote control, DJI Phantom FC40 \& smartphone.

\subsection{Planning and preparation}

Rigorous planning prior flight made to avoid things that are not expected to determine the distance between UAV and building must be less or equal to $2 \mathrm{~m}$ [9] (Fig. 2). The direction of UAV line of flight in vertically [10] as shows in Fig. 3. The direction of flight starting from the bottom moves upward until the top of the building or at the roof and moves to the right side and slowly downward until reaches the ground. This steps repeat until the end of the building.

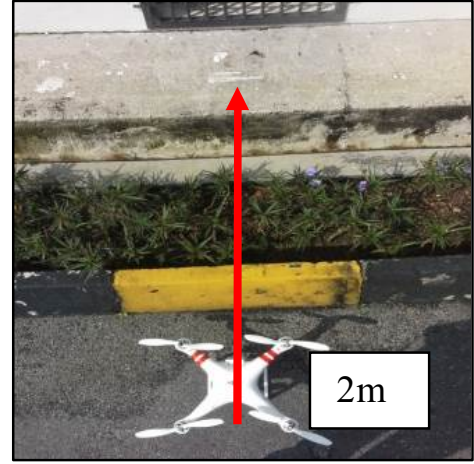

Fig. 2. Distance between UAV and building

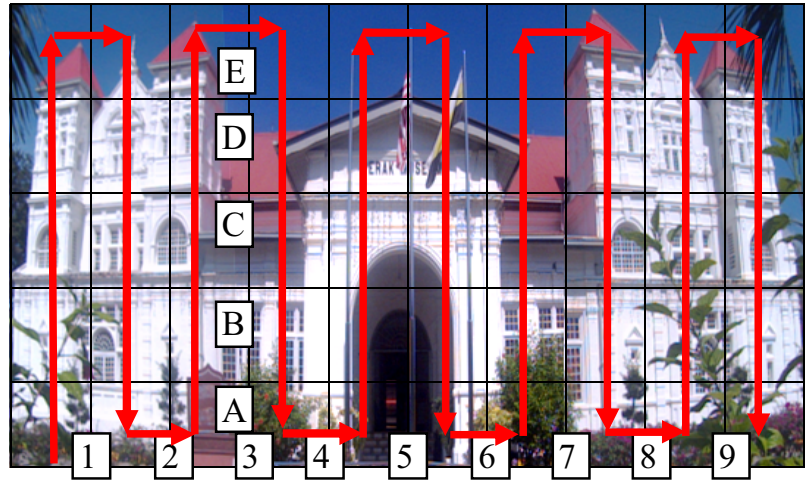

Fig.3. Direction of flight

\subsection{Data collection}

Recording image and video from UAV camera is the method of collecting data. Because of the museum is bigger, the study divided the data collection into 3 phase. There are right side, front and left side. To conduct this research, at least need 2 persons involve while flying the UAV. One of them will control the remote of UAV and another one person need to monitor the smartphone and give the direction to the controller. There are 26 videos taken as the data for this research to show the whole building and to analysis the video. 
Table 1 shows total number of data collecting on site and Fig. 4 shows the system were setup and data collection conducted.

Table 1. Data collection

\begin{tabular}{|c|c|c|c|}
\hline Parts of Building & Video & Image & Editing Image \\
\hline Right & 3 & 38 & 26 \\
\hline Front & 9 & 105 & 28 \\
\hline Left & 10 & 101 & 42 \\
\hline Behind & 4 & 16 & 8 \\
\hline Total & 26 & 260 & 104 \\
\hline
\end{tabular}

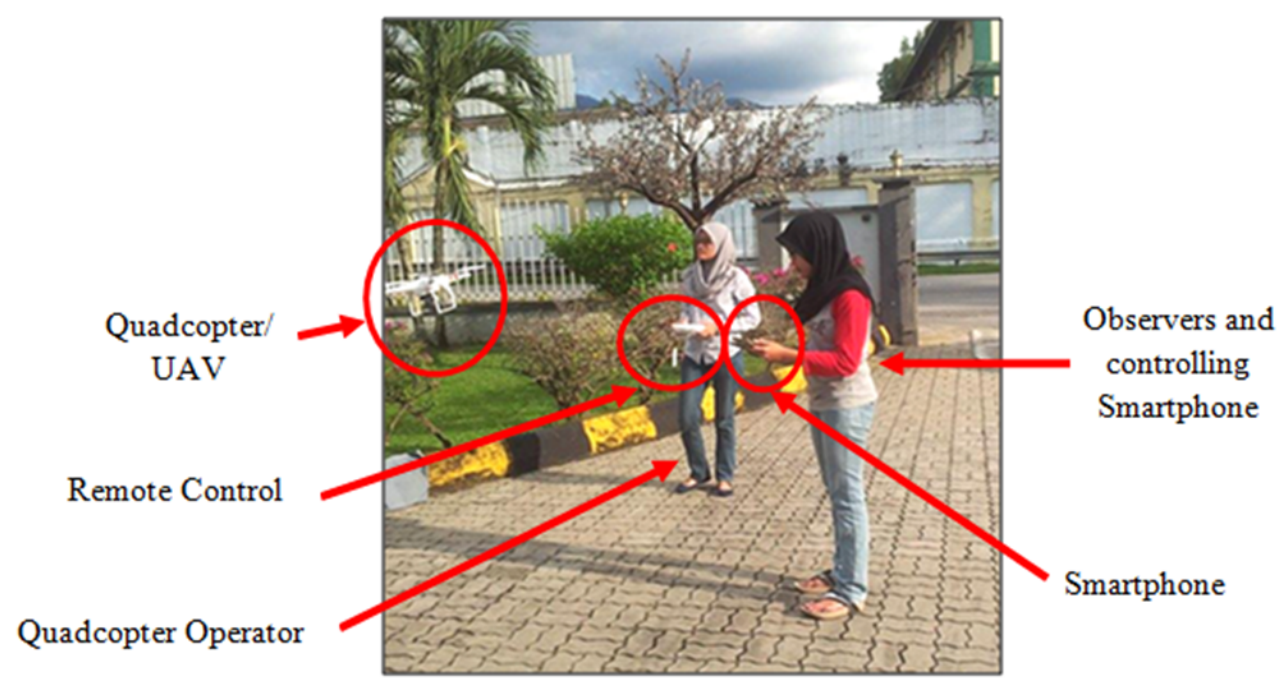

Fig. 4. System setup and Data Collection

\subsection{Image processing}

From the video that have been taken from the site, extra process needs to be done into the image version as the effective way to shows the defect for the building. The step that involves in this process is from the video then play in the VLC Media Player and "Take Snapshot" for defect detects and open the image in Adobe Photoshop. From Adobe Photoshop, the image will be zooming in the display clearly the defect and the brightness and contrast will be adjusted to enhance the image result. The total of image that has been edited by using Adobe Photoshop is 104 pictures. From the edited image, there are 91 defect has been detected for the whole building and Table 2 shows, 3 image has identify the type of defect and location of defect. 
Table 2. Image processing

\begin{tabular}{|c|c|c|c|c|}
\hline No. & $\begin{array}{c}\text { Location \& } \\
\text { Type of } \\
\text { Defect }\end{array}$ & $\begin{array}{c}\text { Image } \\
\text { Editing } \\
\text { Method } \\
\text { Used to } \\
\text { Identify } \\
\text { Defect }\end{array}$ & Image Defect & Zoom Image \\
\hline 1. & $\begin{array}{l}\text { Right Side } \\
\text { Frame } \\
\text { decayed }\end{array}$ & $\begin{array}{l}\text { Ink Outline } \\
\text { Method }\end{array}$ & IIt & \\
\hline 2. & $\begin{array}{l}\text { Front Side } \\
\text { Fungus }\end{array}$ & $\begin{array}{l}\text { Trace } \\
\text { Contour } \\
\text { Method }\end{array}$ & & \\
\hline 3. & $\begin{array}{c}\text { Left Side } \\
\text { Gutter rusted } \\
\text { and rotted }\end{array}$ & $\begin{array}{l}\text { Trace } \\
\text { Contour } \\
\text { Method }\end{array}$ & & \\
\hline
\end{tabular}

\subsection{Analysis of study}

Through the image processing technique using Adobe Photoshop the total number of defects that occur can be identify. The defect has been choose for analysis is based on the repetition occurring. This stage will help to analysis the defect in different way from image processing that just zoom the image. Adobe Photoshop has been use to shows clearly the defect occur. Fig. 5 shows the image editing technique using 'Ink Outlines' method for frame decayed. The black color at the image after editing provide an indicator of broken or missing frame.

Fig. 6 show defect of fungus that occur at the front side of the building. For this defect, the research use Gradient Map and Trace Contour to make the defect shown clearly. It need couple of editing because of the first editing do not get excellent result and the image with colored dots representing fungus on the surface of the building. Fig. 7 show defect of gutters rusted and rotted. By using Brush Strokes Accented Edges, the rusted and rotted part visible clearly and the circle represent the defect. 


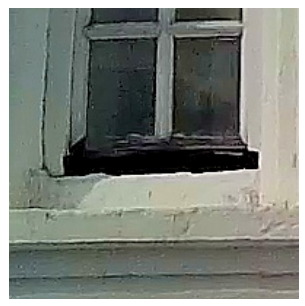

Origional shape

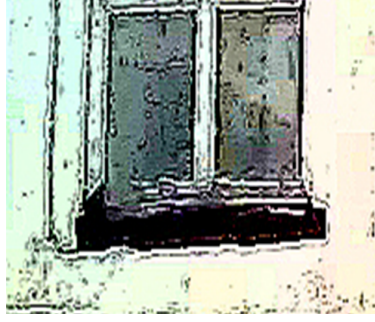

After using 'Ink Outlines' method

Fig. 5. Analysis for frame decayed

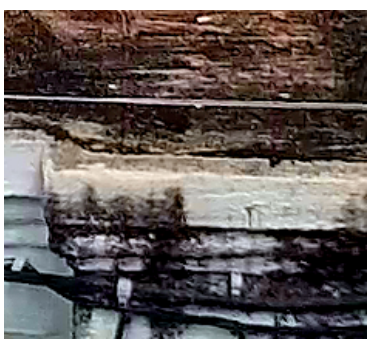

Original image

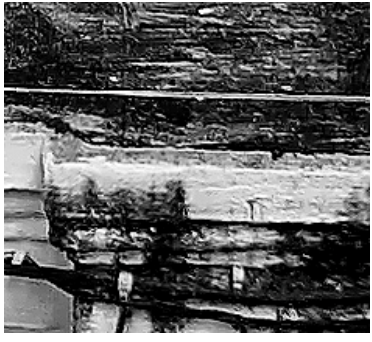

Edit using Gradient Map

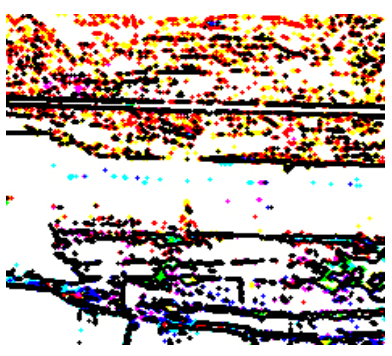

Edit using Trace Contour

Fig. 6. Analysis for fungus.

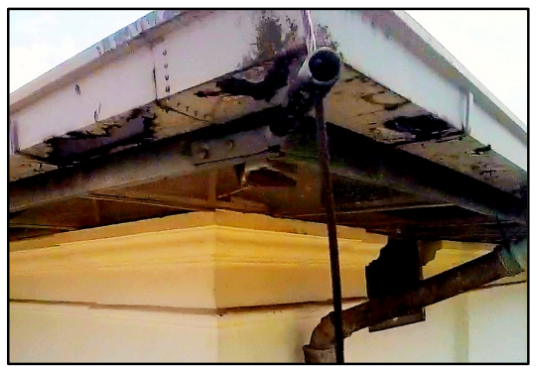

Before edit using Adobe Photoshop

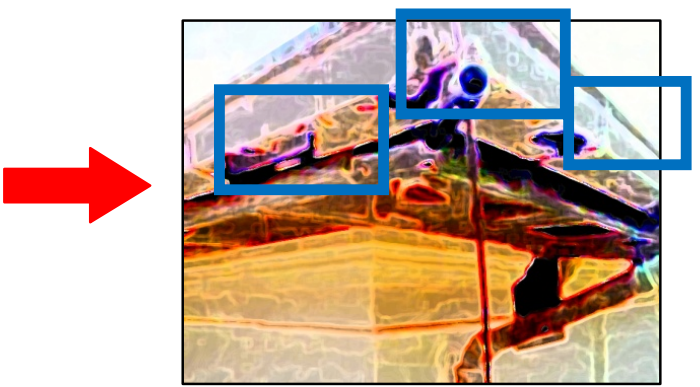

After using 'Brush Strokes Accented Edges'

Fig. 7. Analysis for gutter rusted and rotted.

During the process of improvement of images, more than one an editing process to ensure that all the effects of the defect becomes clearer. For example, the process of brush strokes is more suitable to improve the image of the line as the image of the gutter.

\section{Results and discussions}

From image processing, the total number of defect has been can be identified. The Table 3 shows the data of defect occur at Perak Museum by the section of the building. From the table, the type of defect and the total defect can be recognized and categorized according to the section of the building. 
Table 3. Type and total defect by section.

\begin{tabular}{|c|c|c|c|}
\hline Section & Type of defect & Total defect & Total \\
\hline \multirow{4}{*}{ Right } & Frame decayed & 2 & \multirow{4}{*}{5} \\
\hline & Vegetation & 1 & \\
\hline & Perforated pipe & 1 & \\
\hline & Discoloration & 1 & \\
\hline \multirow{12}{*}{ Front } & Frame decayed & 4 & \multirow{12}{*}{32} \\
\hline & Vegetation & 7 & \\
\hline & Discoloration & 1 & \\
\hline & Peeling paint & 3 & \\
\hline & Clogged gutters & 1 & \\
\hline & Fungus & 5 & \\
\hline & Dirt & 3 & \\
\hline & Broken mirror & 2 & \\
\hline & Gutters rusted and rotted & 2 & \\
\hline & Cleft, Crack & 2 & \\
\hline & Eroded surface & 1 & \\
\hline & Faded paint & 1 & \\
\hline \multirow{11}{*}{ Left } & Frame decayed & 3 & \multirow{11}{*}{44} \\
\hline & Vegetation & 2 & \\
\hline & Peeling paint & 6 & \\
\hline & Fungus & 9 & \\
\hline & Dirt & 1 & \\
\hline & Gutters rusted and rotted & 4 & \\
\hline & Cleft, Crack & 5 & \\
\hline & Eroded surface & 5 & \\
\hline & Faded paint & 3 & \\
\hline & Moldy pipeline & 4 & \\
\hline & Roof broken/dirty & 2 & \\
\hline \multirow{5}{*}{ Back } & Frame decayed & 1 & \multirow{5}{*}{10} \\
\hline & Discoloration & 1 & \\
\hline & Peeling paint & 3 & \\
\hline & Fungus & 4 & \\
\hline & Wall rupture & 1 & \\
\hline
\end{tabular}

From table 2, the top 7 defect occur at museum building is fungus, peeling paint, frame decayed, vegetation, cleft and crack, gutters rusted and rotted and eroded surface.

\section{Conclusions}

By using unmanned aerial vehicle (UAV) to visual inspection of the building is the alternative technique to know the defect occur at exterior of the building. Research has been prove by using the UAVs is visual recording provide information for inspection of the building. Besides that, image processing and analysis will shows in detail the defect occur and the severity of the defect for the building. Also, inspection of building using UAV will help to minimize the cost of operation, reduce time and friendly user. 
This research was supported supported by Short Term Grant, U385 UTHM. We thank our colleagues from PPD and FKAAS who provided insight and expertise that greatly assisted the research, although they may not agree with all of the interpretations/conclusions of this paper.

\section{References}

[1] Jabatan Warisan Negara, Garis Panduan Pemuliharaan Bangunan Warisan, Jabatan Warisan Negara, Kementerian Pelancongan Dan Kebudayaan Malaysia, Kuala Lumpur, Malaysia (2016)

[2] A Ghafar Ahmad, Understanding common building defects: the dilapidation survey report. Majalah Arkitek, 16(1), 19-21 (2004).

[3] A. Ghafar Ahmad, Rangka Kerja Pemuliharaan Bangunan Warisan di Malaysia, (2006), Retrieved on October 15, 2016 from http://www.hbp.usm.my/ conservation/ Sejarah@Msia/Rangka\%20Kerja.htm

[4] J. Unger, M. Reich \& C. Heipke, UAV-based photogrammetry: monitoring of a building zone. The International Archives of Photogrammetry, Remote Sensing and Spatial Information Sciences, 40(5), 601-606 (2014).

[5] A.M. Samad, N. Kamarulzaman, M.A. Hamdani, T.A. Mastor, The potential of Unmanned Aerial Vehicle (UAV) for civilian and maping application. Proc. Of 3rd International Conference on System Engineering and Technology, Shah Alam, Malaysia, (2013)

[6] N. Darwin, A. Ahmad, and O. Zainon, The potential of unmanned aerial vehicle for large scale mapping of coastal area. IOP Conference Series: Earth and Environmental Science 18(1), 1-6. (2014)

[7] I. Ibrahim, Penggunaan UAV bagi applikasi awam., (2009) Retrieved on October 15, 2016 from http://gisondemand.blogspot.my/2009/08/penggunan-uav-bagi-applikasiawam.html

[8] Masiri Kaamin, Misbahul Muneer Abd Rahman, Norhayati Ngadiman, Aslila Abd Kadir, Ahmad Hakimi Mat Nor, Nor Baizura Hamid, and Mardiha Mokhtar, Visual inspection of historical buildings using Unmanned Aerial Vehicles (UAV): A case study of Sultan Abu Bakar Mosque, Johor, Advanced Science Letters, 22(9), 21602163 (2016)

[9] Masiri Kaamin, Nurunnazifah Abd Aziz, Saifullizan Mohd Bukari, Zaurin Ali, Norhafiza Samion, Aslila Abd Kadir, and Norhayati Ngadiman. Kaedah pemeriksaan bangunan tinggi menggunakan pesawat tanpa pemandu (UAV) Jurnal Teknologi 78(510), 83-89 (2016)

[10]C. Eschmann, C.M. Kuo, C.H. Kuo, and C. Boller, Unmanned aircraft systems for remote building inspection and monitoring. Proc. of the 6th European workshop on structural health monitoring, DGZIP, Germany (2012) 